\title{
MANAJEMEN TRAFIK MENGGUNAKAN HTB UNTUK MENINGKATKAN KUALITAS LAYANAN IP NETWORK
}

\author{
(Traffic Management Using HTB to Improve IP Network Service Quality) \\ Bayu Widodo ${ }^{1}$ \\ ${ }^{1}$ Sekolah Vokasi, Institut Pertanian Bogor, Jl. Kumbang No. 14 Bogor, Jawa Barat \\ E-mail : bayuwi@aps.ipb.ac.id
}

Diterima 2 Juli 2021/Disetujui 29 Agustus 2021

\begin{abstract}
In IP-based networks with many users, a bandwidth usage regulation mechanism is needed to ensure service quality. Mikrotik RouterOS has a feature to run QoS known as queue. RouterOS uses the Hierarchichal Token Bucket (HTB) method as the main queue method. The results of the tests carried out show that HTB is able to provide traffic limitation facilities for each classification and guarantee or ensure the amount of bandwidth is less or equal to the predetermined amount. If there is unused bandwidth it can be used by a lower classification (borrowing mechanism).
\end{abstract}

Key Words: Hierarchichal Token Bucket, Queue Tree, Firewall Mangle

\section{PENDAHULUAN}

Saat ini, Internet, World Wide Web, dan Information Super Highway adalah istilah yang tidak asing lagi bagi jutaan orang di seluruh dunia. Transmission Control Protocol/ Internet Protocol (TCP/IP) adalah rangkaian protokol yang dikembangkan untuk Internet. TCP/IP dikembangkan dengan tidak tergantung dengan sistem operasi atau perangkat keras tertentu dan menjadi standar de facto jaringan komputer global. Terlepas dari aplikasi atau layanan non real-time (tradisional) seperti WWW, e-mail, File Transfer Protocol (FTP), maupun layanan yang bersifat real-time seperti layanan VolP, TCP/IP telah mengubah paradigma hidup (Rodriguez et al. n.d.) (Nayak, Rai, and Mall 2016) (Hunt 1992).

Perkembangan berbagai jenis layanan ini tidak akan berhasil tanpa dukungan teknologi berbasis protokol Internet (Internet Protocol/IP) dengan kapasitas dan data rate (bandwidth) yang mampu menangani trafik dalam jumlah yang sangat besar. Interkoneksi pada jaringan IP dibedakan interkoneksi pada managed network dan interkoneksi pada unmanaged network. Interkoneksi pada unmanaged network atau disebut juga sebagai best-effort merupakan interkoneksi antara jaringan dengan layanan aplikasi (konten) tanpa ada pengendalian trafik dan kualitas layanan.

Pada perkembangannya untuk aplikasi/ layanan tertentu interkoneksi yang bersifat Best-Effort tidaklah cukup. Untuk memenuhi kebutuhan-kebutuhan layanan yang berbeda, yang menggunakan infrastruktur yang sama perlu ada mekanisme lain yang disebut sebagai Quality of Service (QoS). QoS merupakan 
suatu tantangan yang besar dalam jaringan berbasis IP dan internet secara keseluruhan. Fitur yang dimiliki QoS menjadikan bandwidth, jitter, latency dapat diprediksi dan dicocokkan dengan kebutuhan aplikasi yang digunakan di dalam jaringan (Rodriguez et al. n.d.) (Hunt 1992).

Salah satu metode implementasi QoS pada jaringan adalah dengan pengendalian trafik jaringan atau dengan melakukan manajemen bandwidth. Manajemen bandwidth dimaksudkan agar bandwidth sebagai sumber daya terbatas dapat digunakan oleh pengguna secara adil dan tepat guna. RouterOS sebagai sistem operasi berbasis Linux yang diperuntukkan sebagai network router telah dilengkapi dengan berbagai fitur queue yang dapat melakukan pengaturan alokasi bandwidth bagi setiap user (Balan and Potorac 2009) (Hidayat 2018).

Fokus penelitian ini adalah membangun adaptive manajemen bandwidth HTB yang diimplementasikan pada Mikrotik RouterOS yang berperan sebagai Internet gateway diantara jaringan lokal dan jaringan Internet (publik). Routerakan mengatur lalu lintas Internet baik yang masuk maupun keluar jaringan lokal dan sekaligus mengalokasikan bandwidth untuk setiap user atau kelompok user yang ada di jaringan lokal, memberikan level layanan sesuai kebutuhan dan prioritas sesuai kebutuhan. Pengalokasian bandwidth yang tepat dapat menjadi salah satu metode dalam memberikan jaminan kualitas suatu layanan jaringan (Balan and Potorac 2009) (Manual n.d.) (Lee and Kim 2013) .

Hasil dari penelitian ini adalah suatu mekanisme pengaturan bandwidth dengan tujuan mencegah terjadinya monopoli penggunaan bandwidth atau terjadi pemakaian bandwidth secara berlebihan oleh satu atau beberapa user dan memberikan jaminan alokasi bandwidth minimum kepada setiap user di dalam jaringan.

\section{STUDI LITERATUR}

\section{Aliran Paket Data}

Jaringan komputer atau jaringan telekomunikasi biasanya didefinisikan sebagai interkoneksi dua komputer autonomous atau lebih untuk keperluan komunikasi data. Setiap komputer yang terhubung dengan jaringan disebut node. Jaringan lokal dan Internet sebagian besar menggunakan TCP/IP sebagai protokolnya. Protokol IP merupakan salah satu protokol kunci di dalam kumpulan protocol TCP/IP. TCP dan IP merupakan jantung protokol Internet. TCP bekerjasama dengan IP mengirimkan data antar komputer melintasi jaringan atau Internet (Rodriguez et al. n.d.) (Hunt 1992) (M 2001) (Cip et al. 2019).

Informasi yang dikirimkan dari komputer ke Internet dan sebaliknya akan diolah oleh protokol TCP/IP menjadi paket-paket yang lebih kecil. Paket akan beredar di jaringan lokal ataupun Internet melewati beberapa router. Router sebagai intermediary device akan menjalankan fungsi routing dan fungsi menentukan paket mana yang akan lebih dahulu dikirimkan dan paket mana yang harus berada di dalam antrian. Paket yang melewati router adalah paket paket yang dibangkitkan oleh komputer user (klien). Istilah Packet flow merupakan sebutan alur proses paket yang keluar dan masuk melewati router (Smansub et al. 2019) (Nayak, Rai, and Mall 2016) (Burgess 2011) . 


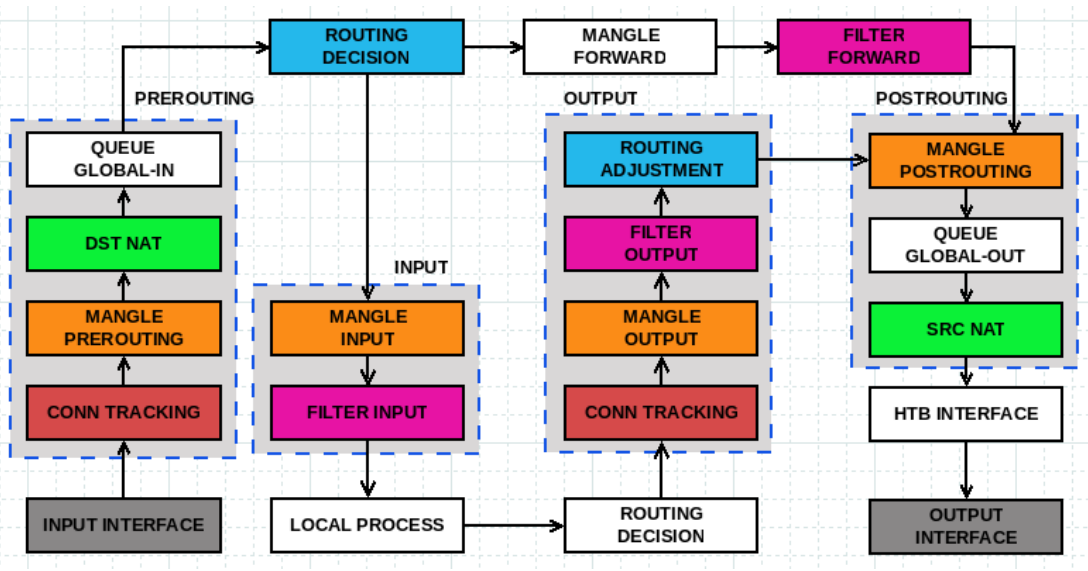

Gambar 1 Paket Flow

Informasi-informasi yang dikirim dari komputer klien ke internet maupun sebaliknya akan diolah oleh protocol TCP/IP menjadi paket. Pada Gambar 1 memperlihatkan bagaimana paket-paket data masuk dari interface input, melewati, atau keluar dari Mikrotik RouterOS (interface output). Paket upload ke internet, trafik upload yang berasal dari LAN akan melewati router. Di dalam router, chain Firewall yang akan dilewati adalah chain prerouting, chain forward dan chain postrouting. Chain prerouting berguna untuk melakukan marking terhadap paket yang akan melintasi router ataupun paket yang akan menuju router. Chain Forward hanya akan melakukan marking pada paket yang melintasi paket dan bukan terhadap paket yang menuju router.

Chain Postrouting pada Firewall Mangle digunakan untuk melakukan marking terhadap paket yang melintasi router maupun paket yang berasal dari router. Jika dilihat pada Gambar 1 terlihat bahwa ada 2 anak panah yang masuk ke dalam chain postrouting. Jika router memiliki 2 (dua) interface di mana interface pertama (eth0) terhubung ke Internet dan interface kedua (eth1) terhubung ke jaringan lokal, maka hasil akhir yang didapat dari konfigurasi pada Gambar 1, adalah 2 (dua) jenis paket, masing-masing paket bisa diindentifikasi sebagai client upload dan client download. (Marcel 2018) (Nayak, Rai, and Mall 2016) (Burgess 2011)

\section{Antrian (Queue)}

Trafik jaringan berhubungan dengan paket data yang dibangkitkan oleh kartu ethernet/ interface perangkat jaringan. Paket paket dikirimkan dari asal ke tujuan melewati link (media) dengan kapasistas (bandwidth) tertentu. Untuk jaringan lokal masalah bandwidth (kapasitas link) tidak terlalu menjadi masalah, karena bandwidth lebih ditentukan oleh kapasitas perangkat router, switch dan kabel yang digunakan.

Masalah akan muncul saat jaringan terhubung ke jaringan publik (Internet), karena umumnya besar bandwidth yang berasal dari Internet sangat terbatas. Jika bandwidth yang tersedia tidak cukup untuk mengalirkan paket-paket data atau jumlah paket yang dikirim lebih banyak dibandingkan dengan kemampuan link untuk menampung atau menyalurkan paket maka akan timbul masalah congesti 
atau kejenuhan. Kondisi trafik semacam ini akan mengakibatkan perfomansi jaringan menjadi menurun, apalagi jika jumlah node yang ada di dalam jaringan sangat banyak.

Cara terbaik untuk mengatasi kongesti trafik adalah dengan meningkatkan kapasitas bandwidth jaringan. Namun, cara ini tidak praktis dalam hal biaya operasi dan pemeliharaan. Cara mengurangi penurunan performansi jaringan tanpa perlu melakukan penambahan biaya atau kapasitas bandwidth adalah dengan menerapkan manajemen bandwidth yakni memaksa paket-paket tersebut masuk ke dalam antrian (queue). Dengan kata lain, interface jaringan harus memiliki kemampuan untuk ingress queue (inbond) dan engress queue (outbond). Ingress queue akan menyimpan paket untuk sementara waktu sebelum paket tersebut diserahkan ke kernel untuk diproses dan selanjutnya diserahkan ke interface yang digunakan untuk mengirimkan paket tersebut. Sebelum paket dikeluarkan dari interface output, paket tersebut terlebih dahulu disimpan di dalam egress queue. (Kuperman, Mikityanskiy, and Efraim n.d.) (Iswadi, Adriman, and Munadi 2019) (Lee and Kim 2013)

Queue pada perangkat jaringan dibedakan antara hardware queue dan software queue. Hardware queue sangat bergantung dengan kapasitas bandwidth interface. Hardware queue dikenal sebagai Transmit Queue(TxQ) atau TX-ring. Hardware queue terjadi di sisi output interface sesaat sebelum paket dikirimkan ke jaringan. Software queue terjadi atau dibutuhkan jika hardware queue tidak mampu menangani kejenuhan jaringan (congesti). Software queue lebih rumit dibandingkan dengan hardware queue. Hardware queue menggunakan metode lebih sederhana dengan hanya menggunakan metode FIFO (First IN First Out), sedangkan software queue dapat diterapkan berbagai metode seperti FIFO,WRR, HTB, CBWFQ, RED (Balan and Potorac 2009) (Iswadi, Adriman, and Munadi 2019).

\section{Paket Marking}

Mangle merupakan salah satu fitur pada firewall Mikrotik RouterOS yang digunakan untuk menandai paket. Pemberian label atau nama kepada setiap paket akan memudahkan router untuk mengelola paket tersebut. Mangle mengenal 3 (tiga) jenis marking, yaitu Connection Mark, Packet Mark dan Route Mark. Dalam jaringan komputer, bisa saja terjadi komputer klien membuat koneksi secara bersama-sama, sehingga router harus menandai paket-paket yang datang. Tahap pertama router melakukan marking bagi semua jenis koneksi yang dibuat oleh semua komputer klien, kemudian router akan melakukan marking terhadap keseluruhan trafik upload maupun trafik download. Pada saat melakukan konfigurasi packet mark pada trafik upload, konfigurasi harus berisi parameter connection-mark=client- $A \_C O N N$ dan parameter in-interface=ether yang disesuaikan dengan interface mana semua trafik upload akan masuk. Sedangkan untuk melakukan marking terhadap paket download parameter connection-mark yang harus digunakan adalah all-clinet_CONN dan in-interface=ether dimana semua trafik download dari Internet akan masuk melalui interface tersebut (Manual n.d.) (Burgess 2011). 


\section{Queue Pada Mikrotik RouterOS}

Manajemen bandwidth merupakan suatu istilah yang ditujukan pada suatu subsistem antrian paket pada suatu jaringan atau network devices. RouterOS sebagai sistem operasi router sudah dilengkapi dengan fitur-fitur untuk menjalankan QoS atau lebih dikenal dengan manajemen bandwidth. Ada 2 cara (metode) RouterOS melakukan fungsi manajemen bandwidth terhadap paket yang diterimanya yaitu: Queue Simple dan queue tree. Kedua metode tersebut sama sama memanfaatkan memory RAM di router sebagai bufer penampuangan antrian paket. Bufer memiliki batas kapasitas, jika antrian paket telah memenuhi buffer maka paket yang tidak tertampung akan di Drop. Jika aplikasi menggunakan protokol TCP, maka paket yang telah didrop akan dikrim ulang (Hardiman 2018) (Ivancic, Hadjina, and Basch 2005) (M 2001).

Queue Simple merupakan cara termudah untuk melakukan pengaturan bandwidth seperti membatasi pemakaian bandwidth upload dan download setiap user. Simple queue dapat melimit upload, download atau total (upload+download) sekaligus dalam 1 rule (Manual n.d.).

Queue tree merupakan penerapan queue yang lebih rumit dibandingkan dengan queue simple. Queue tree dapat melakukan pembatasan bandwidth berdasarkan grup atau kelas tertentu, melakukan skala prioritas bahkan dapat melakukan pembatasan bandwidth secara hirarki. Untuk menggunakan metode antrian queue tree ini, harus melakukan classification packet dan marking packet dengan menggunakan fitur Mangle pada Firewall. Queue tree tidak dapat berjalan tanpa Mangle. Batas maksimum dan minimum alokasi bandwidth yang diterima oleh user diatur oleh parameter CIR dan MIR.

Metoda metoda queue pada RouterOS baik simple queue maupun queue tree pada intinya bekerja untuk mengendalikan atau membatasi rate dari packet flow yang diterima ataupun paket yang akan dikirim melalui interface router.

Mikrotk routerOS mempunyai dua cara untuk membatasi rate dari aliran paket, yaitu rate limiting (dropper/ shaper) dan rate equalizing (scheduller). Rate limiting atau shaper adalah prinsip pembatasan atau pengaturan rate dengan cara membuang paket paket jika paket yang akan diproses lebih besar dari rate yang telah ditentukan. Sedangkan rate equalizing atau scheduler akan menyimpan paket paket yang melebihi rate yang telah ditentukan untuk sementara waktu di dalam queue dan akan dikirim jika kondisi memungkinkan.

Rate scheduller terdiri dari metode queue FIFO (Bytes FIFO, Packets FIFO, Multi Queue Packets FIFO), RED dan SFQ. Sedangkan Rate Shaper teridiri dari metode queue PCQ dan HTB. Gambar 2 berikut memperlihatkan bagaimana bandwidth shaper dan Bandwidth scheduler bekerja untuk membatasi kelebihan paket dari rate yang sudah ditentukan. 

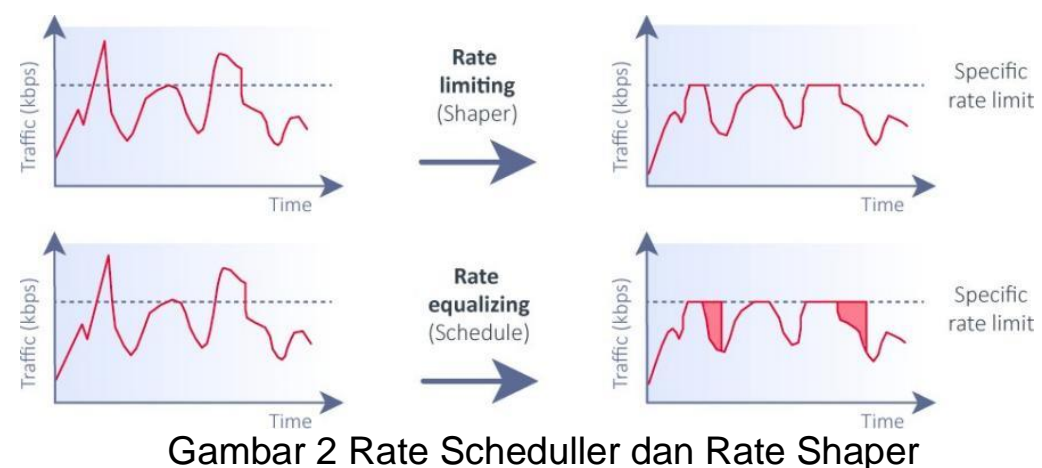

Sumber: www.help.Mikrotik.com

Terlihat pada Gambar 2, dalam kasus pertama, semua trafik melebihi rate yang telah ditentukan dan dihentikan. Dalam kasus lain, trafik melebihi rate tertentu dan tertunda dalam queue dan akan dikirimkan kemudian jika memungkinkan, tetapi paket hanya dapat ditunda jika antrian tidak penuh. Jika tidak ada lagi ruang dalam buffer antrian, paket-paket akan dijatuhkan (drop).

\section{Hierarchichal Token Bucket}

Implementasi manajemen bandwidth di Mikrotik RouterOS banyak bergantung pada sistem HTB (Hierarchical Token Bucket) sebab queue yang dibuat di routerOS disusun berdasarkan prinsip HTB. HTB (Hierarchical Token Bucket) merupakan metode antrian classfull yang mampu menangani berbagai jenis trafik. Teknik antrian HTB akan menghasilkan struktur queue dengan bentuk hirarki (bertingkat) dan mengatur hubungan antar kelas-kelas hirarki dalam bentuk "parent-child" atau "child-child" sehingga metode ini sangat memudahkan dalam pengalokasisan bandwidth (Kuperman, Mikityanskiy, and Efraim n.d.) (Jia et al. 2018).

Inner-class adalah kelas yang memiliki parent-child. Inner queue minimal akan membawahi 1 (satu) leafdan dapat juga queue yang memiliki parent. Dengan kata lain, queue yang memiliki parent dan child dapat dikategorikan sebagai inner queue. Leaf queue membuat konsumsi trafik aktual, inner queue hanya bertanggung jawab untuk distribusi trafik. Di RouterOS perlu menentukan opsi parent untuk menetapkan antrian sebagai child ke antrian lain.

Ketika trafik telah diklasifikasikan, trafik kemudian dijadwalkan (scheduled) and dibentuk (shaped) kemudian HTB akan melakukan tugas-tugas tersebut dengan menggunakan konsep token. Token dihasilkan oleh token generator dengan durasi (interval) yang tetap. Token-token kemudian dikumpulkan dalam bucket untuk mengontrol penggunaan bandwidth dalam link.

Pada Mikrotik RouterOS V5, queue dapat diterapkan pada 4 (empat) bagian yang akan dilewati paket, yaitu: Global-IN (ingress queue), Global-Out (engress queue), Global-Total dan Outgoing interface (output interface). Tiga interface yang pertama merupakan interface virtual sedangkan Outgoing interface merupakan interface fisik. Pemilihan interface mana yang akan dipilih untuk tempat melakukan queue apakah interface virtual ataupun interface fisik tergantung dari skenario jaringan yang dihadapi (Burgess 2011). 
Setiap antrian HTB memiliki dua rate (dual limitation), yaitu MIR (max-limit) dan CIR (limit-at). Maximum Information Rate (MIR) adalah batas maksimum alokasi bandwidth yang dapat diterima oleh user. Beberapa literatur menyebut parameter MIR sebagai Peak Information Rate (PIR). Sedangkan alokasi bandwidth minimum yang masih dapat diterima oleh user ditunjukkan oleh Committed Information Rate (CIR). Seburuk apapun kondisi jaringan, komputer user tidak akan pernah mendapatkan alokasi bandwidth yang lebih rendah dari angka CIR (jaminan mendapatkan bandwidth sebesar limit-at) (Ivancic, Hadjina, and Basch 2005).

Parameter max-limit dan limit-at perlu dikonfigurasikan pada queue untuk memberikan nilai CIR dan MIR kepada user. Parameter limit-at hanya akan berfungsi jika konfigurasi queue dalam bentuk hirarki. Konfigurasi queue dalam bentuk hierarki yang dimaksud adalah konfigurasi queue yang bertindak sebagai parent (inner-queue) dan ada quieue yang bertindak sebagai child (leaf-queue) (Ivancic, Hadjina, and Basch 2005) (Lee and Kim 2013) (Balan and Potorac 2009)

Fitur-fitur yang dimiliki HTB antara lain:

1. Hirarki

- Hampir tidak ada limit hirarki.

2. Grup

- Beberapa klien dapat dikelompokkan dalam satu parent

- Klien tertentu dapat meminjam bandwidth dari klien yang lain dalam grup yang sama, jika dibutuhkan

3. Setiap leaf dapat memiliki pengaturan yang berbeda.

\section{METODE PENELITIAN}

Metode yang dilakukan dalam penelitian ini adalah metode eksperimen yaitu dengan mensimulasikan sistem operasi jaringan RouterOS, merencanakan dan merancang alokasi bandwidth klien sesuai dengan rule queue yang ditetapkan. Tahapan-tahapan yang dilakukan dalam penelitian ini dapat di lihat pada gambar 3. Tahapan tersebut digunakan sebagai sebagai pedoman dalam pelaksanaan penelitian. 


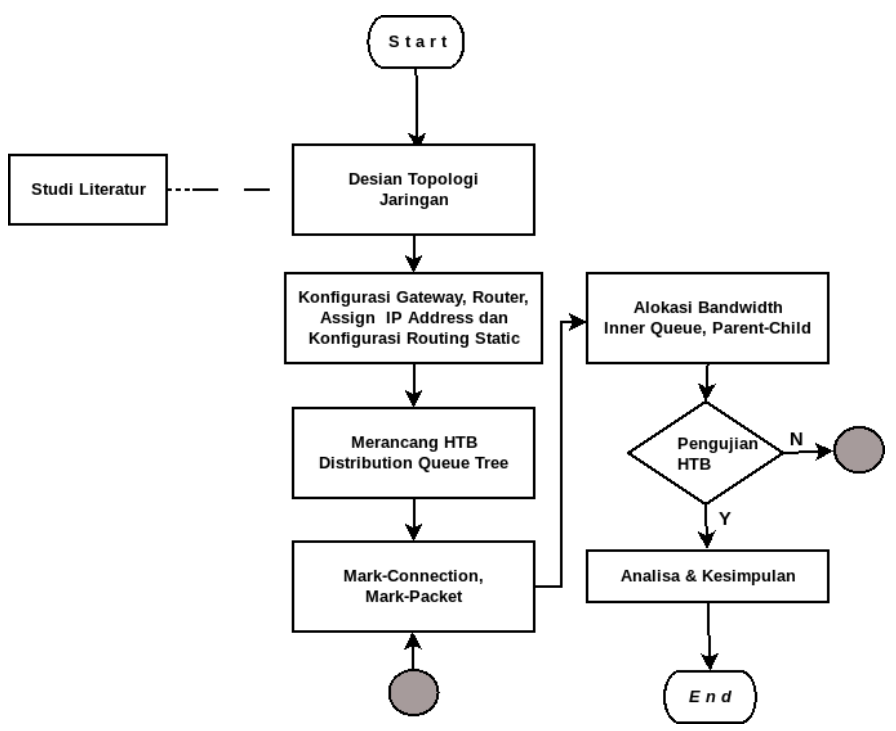

Gambar 3 Metode Penelitian

Strategi awal yang dilakukan adalah dengan melakukan studi pustaka dengan cara mempelajari jurnal terkait dan sumber buku yang berkaitan untuk dikutip sebagai acuan teori dalam mendukung penulisan penelitian ini. Tahapan selanjutnya adalah merancang topologi jaringan dan mensimulasikannya di mesin virtual. Pada tahap selanjutnya melakukan konfigurasi dan test perubahan konfigurasi jaringan terhadap beberapa parameter HTB untuk melakukan klasifikasi, pembatasan trafik dan penentuan prioritas kelas yang akan diutamakan oleh HTB. (Marcel 2018)

Topologi Simulasi Jaringan yang digunakan dalam implementasi Hierarchy Token Bucket tampak seperti pada Gambar 4 berikut :

a. Simulasi yang dirancang terdiri dari 1 (satu) buah router Mikrotik sebagai gateway yang ditempatkan diantara jaringan lokal (LAN) dan jaringan Internet. Jaringan lokal terdiri dari 3 (tiga) buah subnet dan mendapatkan akses Internet dari router Mikrotik. Router Mikrotik selain berperan sebagai gateway juga berperan mengatur trafik Internet baik yang masuk maupun keluar dari subnet tersebut. router Mikrotik akan membagi koneksi Internet (bandwidth) yang didapatkan dari ISP yang kemudian dibagi ke beberapa komputer user yang ada di jaringan lokal.

b. Simulasi jaringan diarahkan untuk menjawab beberapa hal yang menjadi latar belakang dan tujuan yang telah disebutkan sebelumnya. Ketiga subnet masing- masing mewakili grup developer, gru web dan grup mutimedia. Grup developer (grup_dev) merupakan grup dengan subnet /16 dalam simulasi penelitian ini disebut grup16. Grup web merupakan grup dengan subnet /32 disingkat dengan gerup_web dan simulasi penelitian disebut grup32. Grup multimedia yang merupakan grup dengan subnet /40 disingkat dengan gruo_mm dan dalam penelitian disebut grup40.

Pengelompokkan user ke dalam grup yang berbeda didasarkan pada kebutuhan bandwidth yang berbeda pada setiap aplikasi dan transaksi bisnis yang dilakukannya. Secara umum transaksi bisnis setiap grup melalui Internet dengan 
layanan http (web), layanan email (smtp dan pop3), ftp dan layanan multimedia.

Gambar 4 berikut menunjukkan pembagian grup, pembagian subnet dan jumlah user tiap subnet.

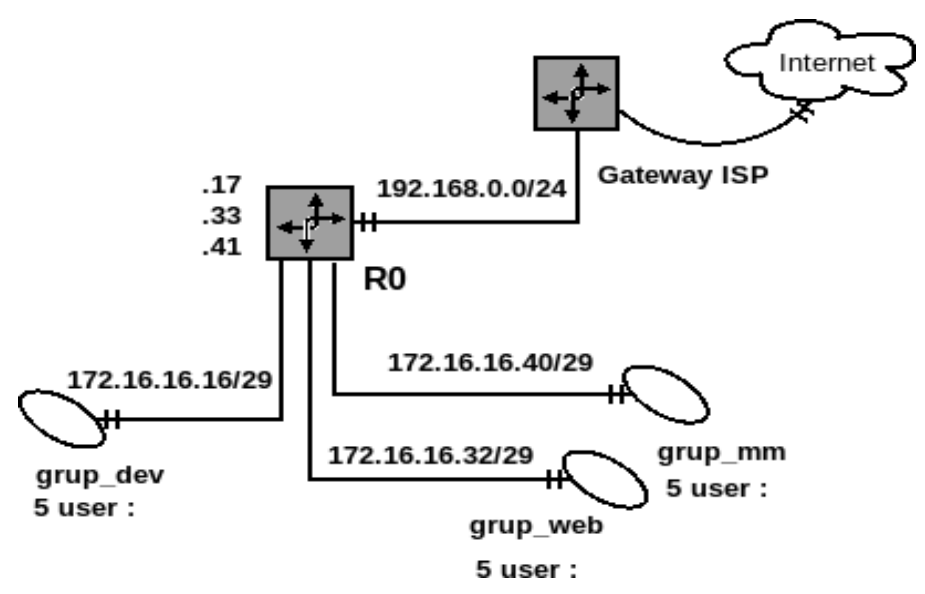

Gambar 4 Topologi Jaringan

1. Subnet 172.16.16.16/29 adalah kelompok user dari grup_dev, subnet 172.16.16.32/29 adalah kelompok user grup_web, dan subnet 172.16.16.40/28 merupakan subnet dari user yang tergabung dalam kelompok grup_mm.

2. R0 merupakan satu satunya jalur menuju jaringan publik (Internet) dengan 4 (empat) buah interface. R0 berperan sebagai default gateway dengan menggunakan mode NAT. Interface eth0 mendapatkan IP Address secara dinamik dari ISP sedangkan interface lainnya menghadap ke router yang melayani subnet jaringan lokal.

3. Perlakuan manajemen bandwidth hanya membedakan trafik download (downstream) untuk setiap grup sesuai dengan konfigurasi queue tree.

Berikut ini adalah tabel detail konfigurasi Mode Network VBox dari skema jaringan sebagaimana terlihat pada Gambar 4.

Tabel 1 Distribusi IP Address

\begin{tabular}{clcccc}
\hline Router & Deskripsi & eth0 & eth1 & eth2 & eth3 \\
\hline \multirow{6}{*}{ R0 } & Mode & Bridged & Int net & Int net & Int net \\
& Nama & - & net16 & net32 & 0 \\
& Network & 192.168 .0 .0 & 172.16 .16 .16 & 172.16 .16 .32 & 172.16 .16 .40 \\
& IP Addr & 192.168 .0 .18 & 172.16 .16 .17 & 172.16 .16 .33 & 172.16 .16 .41 \\
& IP & Internet & subnet 16 & subnet 32 & subnet 40 \\
& Gateway & 192.168 .0 .1 & 172.16 .16 .17 & 172.16 .16 .33 & 172.16 .16 .42 \\
\hline
\end{tabular}




\section{HASIL DAN PEMBAHASAN}

Router Mikrotik (R0) secara default menjalankan hardware queue dengan metode pfifo. Kemampuan hardware queue di setiap interface adalah 50 paket. Artinya selama kongesti terjadi, hardware queue hanya dapat menampung 50 paket. Jika di dalam routersudah ada 50 paket, maka paket yang baru masuk akan didrop. Hardware queue ditempatkan pada output interface sesaat sebelum paket masuk ke dalam media jaringan. HTB dibutuhkan saat hardware queue sudah penuh dan tidak bisa menangani kongesti.

Pada router Mikrotik (R0) dilakukan manajemen bandwidth terhadap subnet 16/29, subnet $32 / 29$ dan subnet 40/29. Pada skenario ini, semua user mendapatkan sharing internet dari R0. Artinya R0 menjalankan Network Address Translation (NAT) yang berfungsi mengganti IP address pada setiap paket data yang keluar dari komputer user menjadi IP address yang ada di eth0 (interface yang menuju Internet).

DNS server yang digunakan adalah DNS server ISP dengan IP Address 192.168.0.1 dengan pilihan allow remote request=yes pada konfigurasinya agar R0 bertindak sebagai DNS server juga. Sehingga konfigurasi DNS pada komputer user cukup diarahkan ke router Mikrotik.

Alokasi bandwidth dari ISP sebesar 3.9 Mbps upload dan 24.0 Mbps download. Bandwidth 24.0 Mbps akan dialokasikan ke grup_dev (grup16), grup_web (grup32), dan grup_mm (grup40). Setiap grup terdiri dari 5 (lima) user sesuai dengan jumlah IP address valid yang ada di dalam setiap subnet.

Dalam penelitian ini, konfigurasi queue yang dibahas hanya untuk alokasi bandwidth download dan interface HTB yang akan digunakan sebagai parent pada konfigurasi adalah interface eth1, interface eth2, interface eth3. Queue akan dilakukan baik di interface eth1, interface eth2 maupun di interface eth3 atau dengan kata lain queue akan dijalankan di router.

Konfigurasi inner queue dilakukan di ketiga interface, dimana dalam kasus ini memiliki 3 (tiga) inner queue dan masing-masing inner queue memiliki 3 (tiga) child (leaf), yakni dedicated, K512, dan K256. Distribusi atau alokasi bandwidth masing-masing kelas dijelaskan sebagai berikut:

1. Inner queue grup16, grup32 dan grup40 membawahi 3 (tiga) konfigurasi leaf queue. Parameter priority 6 diberikan untuk konfigurasi queue dedicated baik grup16, grup32 maupun grup40.

2. Maximum Information Rate (MIR) merupakan parameter HTB yang merupakan nilai maksimum bandwidth yang bisa digunakan oleh setiap class, jika bandwidth melebihi rate maka paket data akan dipotong atau di jatuhkan (drop). Committed Information Rate (CIR) merupakan parameter bandwidth yang menentukan peminjaman bandiwdth antar class. Peminjaman bandwidth dilakukan class paling bawah ke kelas di atasnya. CIR merupakan nilai bandwidth minimum yang akan diperoleh user jika jaringan sedang sibuk.

3. Jika semua klien menggunakan alokasi bandwidthnya, maka masing-masing klien akan mendapatkan bandwidth seperti pada tabel berikut : 
Tabel 2 Strategi Alokasi Bandwidth,Mbps

\begin{tabular}{cccc}
\hline Nama Queue & priority & CIR & MIR \\
\hline grup16 & 7 & 8,0 & 24,0 \\
grup32 & 8 & 8,0 & 24,0 \\
grup40 & 8 & 8,0 & 24,0 \\
dedicated & 6 & 6,0 & 12,0 \\
K512 & 7 & 1,0 & 10,0 \\
K256 & 8 & 1,0 & 10,0 \\
\hline
\end{tabular}

\section{Struktur Queue Tree HTB}

Berangkat dari strategi alokasi bandwidth sebagaimana tabel 2 di atas, diagram hirarki Queue HTB untuk downstream digambarkan pada Gambar 5 berikut.

Strategi alokasi bandiwdth grup16 diberikan prioritas sedikit lebih tinggi dari queue grup yang lain. Konfigurasi queue untuk grup16 menggunakan parameter priority=7, sedangkan grup32 dan grup40 memiliki priority=8. Konfigurasi dengan priority $=7$ akan mendapatkan prioritas yang lebih tinggi dan akan diutamakan.

Class dedicated memiliki prioritas yang lebih tinggi jika dibandingkan dengan class $512 \mathrm{~K}$ dan $256 \mathrm{~K}$. Class dedicated akan lebih diutamakan dibanding queue untuk class yang lain. Class dedicated akan mendapatkan prioritasnya setelah class yang lain mendapatkan alokasi CIR-nya. Skenario alokasi bandiwdth ini tidak akan mengganggu nilai CIR yang sudah dialokasikan untuk masing-masing class.

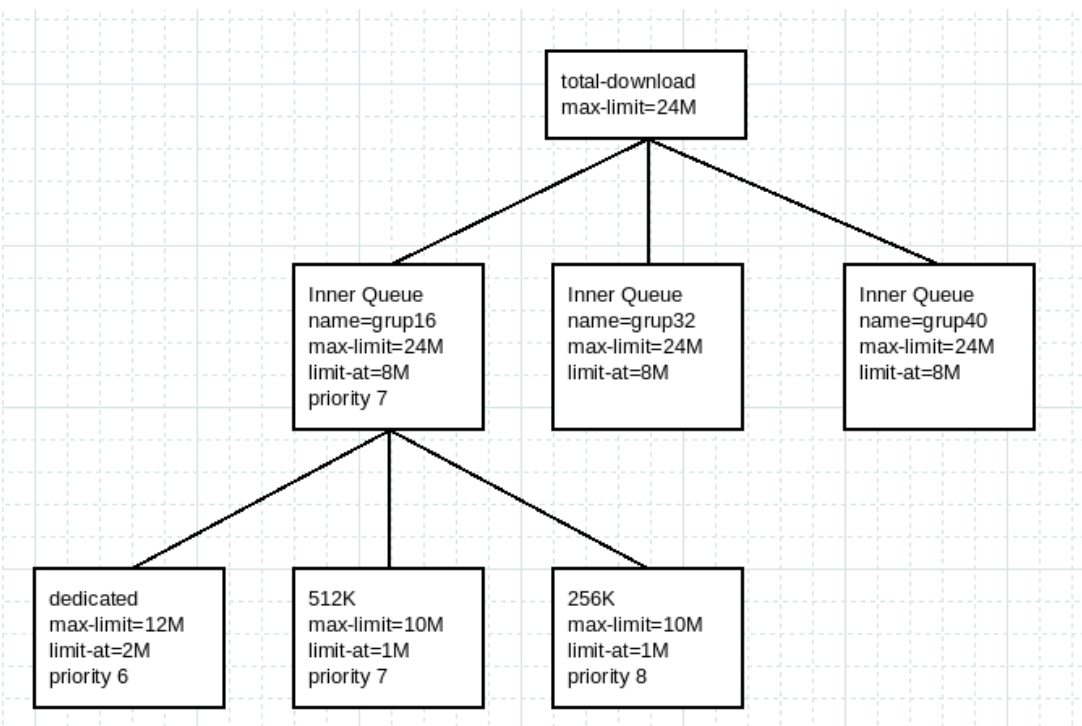

Gambar 5 Strategi Alokasi Bandwidth 


\section{Marking Paket}

Konfigurasi marking paket menggunakan parameter src-address-list terhadap IP Address yang telah didaftarkan pada address list. Berikut adalah contoh address list dan klien dalam kategori address list network 172.16.16.16/29:

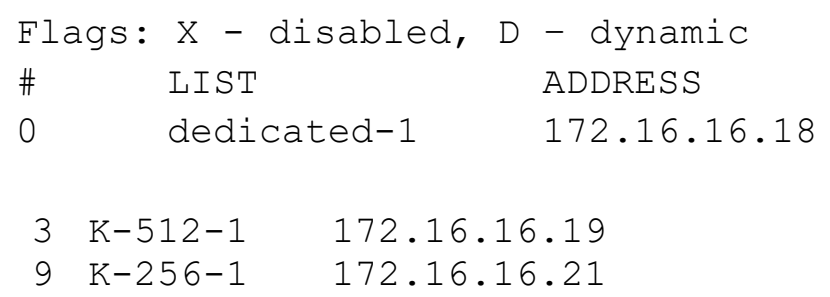

Tahapan berikutnya adalah melakukan marking pada semua jenis koneksi dari kelas yang telah dibuat, tanpa melihat jenis koneksi Internet yang dilakukan menggunakan paramater src-address-list. Hasil marking koneksi untuk interface router adalah sebagai berikut (tidak dituliskan seluruhnya) :

Flags: X - disabled, I - invalid, D - dynamic

$0 \quad$ chain=prerouting action=mark-connection new-connection-mark=dedi-1-con passthrough=yes । src-address-list=dedicated-1 in-interface=eth 1

$1 \quad$ chain=prerouting action=mark-packet new-packetmark=dedil \passthrough=no connection-mark=dedi1 -con ।

6 chain=prerouting action=mark-connection \ newconnection-mark=K5121 passthrough=yes \ srcaddress-list $=\mathrm{K}-512-1$ in-interface $=$ eth 1

7 chain=prerouting action=mark-packet new-packetmark=K5121P \passthrough=no connection-mark=K5121

12 chain=prerouting action=mark-connection \ newconnection-mark=K2561 passthrough=yes srcaddress-list $=\mathrm{K}-256-1$ in-interface $=$ eth 1

13 chain=prerouting action=mark-packet new-packetmark=K2561P \passthrough=no connection-mark=K2561 


\section{Konfigurasi Queue Tree HTB}

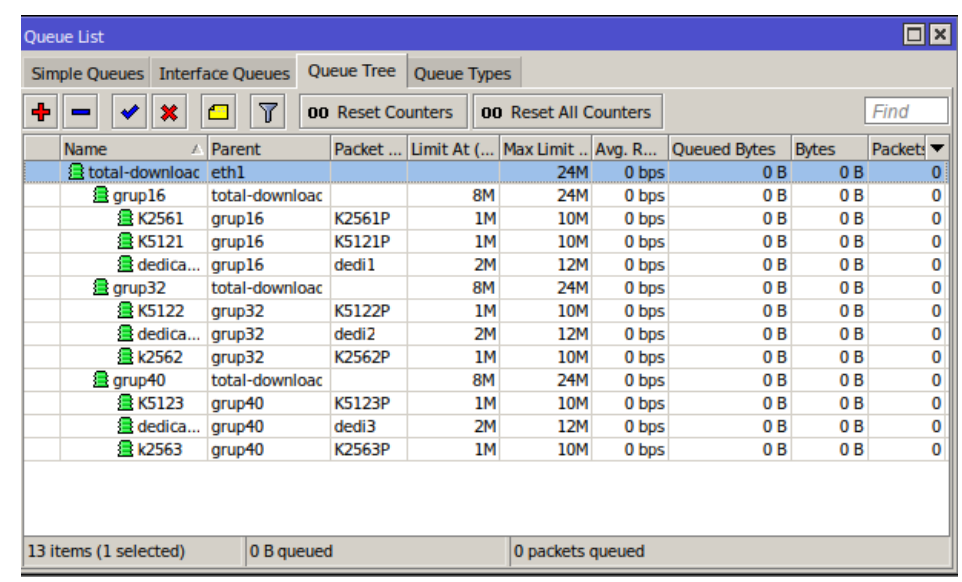

\section{Gambar 6 Pengujian HBT Tree}

Gambar 6 memperlihatkan diagram manajemen bandwidth untuk paket download untuk grup16 dengan 1 (satu) inner queue dan 3 (tiga) buah leaf. Diagram yang sama bisa digambarkan untuk grup32 dan grup40.

Dengan memperhatikan alokasi CIR pada setiap leaf dari ketiga class tersebut dapat ditentukan bahwa leaf dedicated dalam kondisi terburuk tetap akan mendapatkan alokasi bandwidth sebesar 2.0M. Dengan prioritas yang lebih tinggi dibandingkan leaf dalam parent yang sama, leaf dedicated berhak mengambil keseluruhan sisa alokasi bandwidth yang ada dari parentnya. Dari konfigurasi subnet, leaf K521 dan leaf K256 maksimal klien yang dapat dimasukkan dalam kategori ini adalah 2 (dua) klien dan setiap klien dijamin akan mendapatkan CIR 1.0 Mbps dan MIR sampai dengan 10.0 Mbps.

\section{Pengujian}

Tahap pengujian dilakukan untuk mencocokan konfigurasi limitasi bandwidth apakah telah bekerja dengan baik, dalam arti ada perbedaan besar bandwidth sesaat sebelum queue dijalankan di router dan setelah queue dijalankan di router. Uji konfigurasi dilakukan dengan mengukur besar bandwidth upload dan bandwidth download sebelum (pre-HTB) menggunakan queue dan setelah (postHTB) menggunakan queue. Hasil pengukuran menggunakan aplikasi speedtestcli di setiap klien pre-HTB dan post-HTB, seperti pada Tabel 3.

Tabel 3 Hasil Pengukuran Pre-HTB dan Post-HTB

\begin{tabular}{cccc}
\hline No & IP Addr & $\begin{array}{c}\text { Pre-HTB, Mbps } \\
(\mathbf{d} / \mathbf{u})\end{array}$ & $\begin{array}{c}\text { Post-HTB, Mbps } \\
(\mathbf{d} / \mathbf{u})\end{array}$ \\
\hline & Data ISP & & \\
Latency & & 0 \\
1 & Download & & $23,43 \mathrm{Mbps}$ \\
& Upload & $3,88 \mathrm{Mbps}$ \\
& Packet Loss & & $1,4 \%$ \\
\multicolumn{2}{r}{ Test 1 Subnet 16/29 } & & \\
1 & $172.16 .16 .18 / 16$ & $23,56 / 3,17$ & $10,13 / 1,67$
\end{tabular}


2

\section{3}

172.16.16.20/16

172.16.16.22/16

Test 2 Dedicated ketiga subnet

1

2

3

172.16.16.19/16

$172.16 .16 .35 / 32$

$172.16 .16 .19 / 16$
$172.16 .16 .35 / 32$
$172.16 .16 .42 / 40$

$20,95 / 3,44$

$7,97 / 1,41$

$22,47 / 3,15$

$5,45 / 2,81$

$22,42 / 3,4$

$9,93 / 2,22$

$21,67 / 3,76$

$9,95 / 3,79$

$22,95 / 3,34$

$9,23 / 1,91$

Tabel 3 menunjukkan besar bandwidth upload dan download sesungguhnya (throughput) dari ISP. Bandwidth download sebesar 23,43 Mbps dan upload sebesar 3,88 Mbps. Dalam penelitian ini, alokasi bandwidth upload tidak diperhitungkan dengan asumsi bandwidth upload yang diberikan ISP lebih besar dari pemakaian bandwidth upload dari user yang tergabung di dalam setiap subnet.

Dengan memperhatikan throughput tabel 3, saat router Mikrotik tidak menjalankan HTB queue throughput setiap leaf berkisar antara 20 Mbps sampai dengan 23 Mbps. Beberapa faktor yang mempengaruhi perbedaan angka ini antara lain kecepatan modem dan mesin komputer yang digunakan, keadaan jaringan dan banyaknya pengguna yang mnegakses secara bersamaan. Dalam hal ini pengguna yang ada di dalam network 192.168.0.1.

Pada kolom berikutnya pada tabel yang sama, sesuai dengan strategi rancangan yang dikonfigurasi, untuk kelas 16/29 leaf dedicated dialokasikan MIR sebesar $12 \mathrm{Mbps}$ dan CIR sebesar $2 \mathrm{M}$ dengan priority 6 . Terlihat pada tabel postHTB leaf dedicated angka download sebesar 9,93 Mbps yang lebih rendah dari MIRnya. Demikian pula dengan leaf 512 besar download sebesar 7,97 Mbps dan leaf 256 besar bandwidth sebesar 5,45 Mbps. Kedua angka terakhir ini ternyata masih lebih rendah dari angka MIR-nya. Jika melihat priority leaf dedicated sebesar 6 dan lebih tinggi dari leaf yang lain pada kelas yang sama, alokasi bandwidth yang diterima pada kelas yang sama ternyata lebih besar.

Keadaan berikutnya mencoba melihat perbedaan pre-HTB dan post-HTB pada leaf pada inner queue yang berbeda atau leaf pada subnet 16/29, 32/29, dan 40/29. Diperoleh bahwa besar bandwidth di ketiga leaf pada pre-HTB masing masing sebesar 21,42 Mpbs; 21,67 Mpbs; dan 22,95 Mbps. Dengan rancangan MIR dan CIR di setiap leafnya sebagaimana tampak pada Gambar 6 diperoleh bandwidth aktual masing-masing sebesar 9,93 Mbps (MIR 12M), 9,95 (MIR 12 Mbps) Mbps dan 9,23 (12 Mbps) Mbps. Bandwidth yang diperoleh lebih rendah dibandingkan dengan max-limitnya. Teknik HTB mampu mengatur alokasi bandwidth secara hirarki, dan leaf queues adalah pengguna bandwidth sesungguhnya. Sedangkan inner queues untuk perhitungan dan distribusi bandwidth.

\section{SIMPULAN}

Teknik antrian HTB memberikan fasilitas pembatasan trafik pada setiap level maupun klasifikasi namun jika terdapat bandwidth yang tidak terpakai bisa digunakan oleh klasifikasi yang lebih rendah. Teknik antrian HTB merupakan solusi yang efektif ketika penggunaan bandwidth perlu dikontrol dan dikendalikan. 
Metoda HTB mampu memberikan fleksibilitas dalam manajemen bandwidth. HTB memungkinkan membuat queue menjadi lebih terstruktur, dengan melakukan pengelompokan-pengelompokan bertingkat. HTB memastikan jumlah layanan yang disediakan untuk tiap kelas kurang atau sama dengan jumlah yang telah ditetapkan. Ketika sebuah kelas memiliki permintaan yang kurang dari jumlah yang ditetapkan, sisa bandwidth akan didistribusikan ke kelas yang lain.

Parameter prioritas pada queue tree berfungsi memberikan prioritas yang berbeda diantara queue yang ada dan hanya bekerja di leaf queue. Jika parameter priority tidak ditetapkan leaf queue akan menggunakan priority default (nilai 8, priority terendah). Parameter max-limit parent haruslah lebih besar dari jumlah seluruh limit-at childnya.

Nilai max-limit parent harus lebih besar atau sama dengan jumlah dari keseluruhan max-limit child-nya. Jika max-limit child lebih besar dari max-limit parentnya, maka klien tidak akan pernah mencapai trafik sesuai dengan maxlimitnya. Parameter priority hanya berperan sebagai pembagi bandwidth yang tersisa (konsep peminjaman bandwidth dan priority hanya bisa digunakan pada leaf queue.

\section{DAFTAR PUSTAKA}

Burgess, Dennis. 2011. Learn Routeros - Second Edition.

Cip, Cybertraining et al. 2019. Lab 20 : Classifying TCP Traffic Using Hierarchical Token Bucket ( HTB ).

D. G. Balan and D. A. Potorac, "Linux HTB queuing discipline implementations," 2009 First International Conference on Networked Digital Technologies, 2009, pp. 122-126, doi: 10.1109/NDT.2009.5272182..

Hardiman, et al. 2018. "Analisis Perbandingan QoS (Quality Of Service) Pada Manajemen Bandwidth Dengan Metode PCQ (Per Connection Queue) Dan HTB (Hierarchical Token Bucket)." semanTIK 4(1): 121-28.

Hidayat, Arif. 2018. "Comparative Analysis of Mikrotik Site Filter Using Address List Techniques, Layer7 Protocols, Web Proxy, Mangle and DNS Static." International Journal of Engineering and Technology(UAE) 7(3.4 Special Issue 4): 272-75.

Hunt, Craig. 1992. TCP/IP Network Administration. EDITION, T. ed. Mike Loukides and Debra Cameron. O'Reilly Media, Inc.

Iswadi, Defri, Ramzi Adriman, and Rizal Munadi. 2019. "Adaptive Switching PCQHTB Algorithms for Bandwidth Management in RouterOS." Proceedings: CYBERNETICSCOM 2019 - 2019 IEEE International Conference on Cybernetics and Computational Intelligence: Towards a Smart and HumanCentered Cyber World: 61-65.

Ivancic, Dorian, Nikola Hadjina, and Danko Basch. 2005. "Analysis of Precision of the HTB Packet Scheduler." 2005 18th International Conference on Applied Electromagnetics and Communications, ICECom 2005: 1-4.

Jia, Chengjun et al. 2018. "Multi-Core HTB for Bandwidth Sharing." ANCS 2018 Proceedings of the 2018 Symposium on Architectures for Networking and Communications Systems (July): 169-71. 
Konstantinos S.2001."Quality of service for IP-based networks".Tesis.Tidak Diterbitkan.Master of Science in Computer Science and Master of Science in Information Technology Management.Naval Postgraduate School: Monterey, CA

Kuperman, Yossi, Maxim Mikityanskiy, and Rony Efraim. "Hierarchical QoS Hardware Offload (HTB)."

Lee, Chang Hwan, and Young Tak Kim. 2013. "QoS-Aware Hierarchical Token Bucket (QHTB) Queuing Disciplines for QoS-Guaranteed Diffserv

M, Embedded Systems. 2001. "Quality of Service for Packet Networks." (M).

Marcel. 2018. "Performance Evaluation of MikroTik-Based Virtual Machine for Small-Scale Network Virtualization on VMware Platform." Proceedings 2018 International Conference on Control, Electronics, Renewable Energy and Communications, ICCEREC 2018: 154-58.

Mikrotikls SIA. 2007."MikroTik RouterOS ${ }^{\text {TM" }}$ v3.0 Reference Manual. Riga, Latvia: Mikrotik.

Nayak, Ajit Kumar, Satyananda Champati Rai, and Rajib Mall. 2016. Computer Network Simulation Using NS2 Introduction to NS2.

Provisioning with Optimized Bandwidth Utilization and Priority-Based Preemption." International Conference on Information Networking: 351-58.

Rodriguez, Adolfo, John Gatrell, John Karas, and Roland Peschke. "TCP / IP Tutorial and Technical Overview."

Smansub, C., B. Purahong, P. Sithiyopasakul, and C. Benjangkaprasert. 2019. "A Study of Network Bandwidth Management by Using Queue Tree with per Connection Queue." Journal of Physics: Conference Series 1195(1). 